\title{
PAY INEQUALITY AND THE DETERIORATING LABOUR STANDARDS IN CROATIA
}

Ivan Rubinić, mag. oec.*

\author{
UDK: $330.564(497.5)$ \\ https://doi.org/10.30925/zpfsr.40.2.6 \\ Ur.: 1. ožujka 2019. \\ Pr.: 7. svibnja 2019. \\ Izvorni znanstveni rad
}

\section{Summary}

This study furnishes proof in support of the hypothesis that Croatian employees are experiencing persistent worsening of the labour standard alongside the rising divergence in their earnings distribution. The research disclosed five mutually reinforcing tendencies investigated through a widely used Theil index and functional income distribution. The empirical analysis demonstrated the deterioration of the labour standard apparent through the continuous decline in the labour share of income concurrent with productivity growth. The net pay inequality reported a radical increase and stabilization on a higher plane with a nominal improvement brought about as a result of the layoffs predominantly affecting the lower tail of the distribution. Consequently, the lesser earning dispersion came at the expense of the overall rise in inequality. The gross inequality indicated an increasing pattern highly and positively correlated with the movement of the highest earners experiencing a triple-digit population surge. The rising between-county pay inequality throughout the period suggested a strong bias toward excessive centralization, evident with the capital city being the exclusive county consistently reporting above-average earning levels. Lastly, the between-sector pay inequality exhibited an overall decline. This isolated case, however, remains a dominant driver of inequality, given that the lowesthighest earning sector range is approximately double that of the between-county range. These findings are detrimental to the Croatian worker's wellbeing and they pose a challenge to the national policymakers who must counter adverse tendencies in order to circumvent the current exodus of skilled workers, and restore long-term macroeconomic stability.

Keywords: inequality; pay inequality; Theil's T statistic.

\section{INTRODUCTION}

The present-day deluge of academic writings addressing the subject of inequalities emerges as a consequence of hazards generated by acute economic

* Ivan Rubinić, mag. oec., University of Rijeka, Faculty of Law, irubinic1@pravri.hr. 
polarization. The field's leading experts argue that the excessive inequality is both the cause and the consequence of the system's failure, contributing to the instability and endangering the future, ${ }^{1}$ that capitalism generates unsustainable inequalities via limitless wealth increase that undermines meritocratic values and results in a waste of human resources, ${ }^{2}$ and that rising inequality is a sign of a trouble to come. ${ }^{3}$ Others ${ }^{4}$ hold inequality as a natural outcome of the market economy, distributing the rewards in accordance with contributions and prescribing the inequality to a skill-based technological change. Conrad ${ }^{5}$ asserts that the success of the top one percent is an asset rather than a liability, while Watkins and Brook ${ }^{6}$ claim that the purpose of the inequality apologists is to create a land inhospitable to opportunity. These authors advocate for a smaller government and oppose the redistribution by appropriating the logic of Milton and Rose Friedman ${ }^{7}$ stating that society must put freedom ahead of equality, or will end up without either.

While a certain degree of the inequality can be tolerated based on incentive grounds, the author of this paper considers the arguments of the latter group as not compelling and lacking adequate empirical grounds. Their reasoning is, inter alia, debunked by Galbraith ${ }^{8}$ who has shown that the extreme inequalities cannot be legitimized and are an indisputable sign that there is something wrong with the unobstructed competitive model. Accordingly, the author considers it self-evident that the drastic widening of the inequality gap, if left uncontrolled, will result in the plutocracy and the oppression of the weak.

The multidimensional phenomena of economic inequality should to be investigated through the connectedness of its components amongst which the paramount ones include wealth, income, and pay inequalities. Due to the high capital centralization, the wealth inequality is greater than the income inequality, ${ }^{9}$ while the income inequality is greater than the inequality of pay. Given that, the income inequality, in addition to earnings, is comprised of capital gains, dividends, rent, and other incomes. The full complexity surfaces when the matter is investigated holistically. When it is proven that the individuals earning high capital gains are the same ones receiving the highest labour incomes, ${ }^{10}$ and keeping the growth of the poorest as a hostage of the rich. ${ }^{11}$ When it is proven that this dynamic is further

1 Stiglitz, J. E., The Price of Inequality, New York, W. W. Norton \& Company, 2013.

2 See Piketty, T., Capital in the Twenty-First Century, London, Harvard University Press, 2014 and Piketty, T., The Economics of Inequality, London, Harvard University Press, 2015.

3 Galbraith, J. K., Inequality, New York, Oxford University Press, 2016.

4 e.g. Mankiw, G. N., Defending the One Percent, Journal of Economic Perspectives, vol. 27, 3/2013, p. 27.

5 Conrad, E., The Upside of Inequality, New York, Penguin Random House, 2016.

6 Watkins, D., Brook, Y., Equal is Unfair, New York, St. Martin's Press, 2016.

7 Friedman, M., Friedman, R., Free to Choose, New York, Harcourt, 1980.

8 Galbraith, J. K., Created Unequal, Chicago, Chicago University Press, 2000.

9 Milanović, B., Global Inequality, London, Harvard University Press, 2016.

10 Lakner, C., Atkinson, A., Wages, Capital and Top Incomes: The Factor Income Composition of Top Incomes in the USA, 1960-2005, 2014. Available at: www.ecinq.org.

11 van der Weide, R., Milanović, B. Inequality Is Bad for the Growth of the Poor, Policy Research Working Paper, No. 6963, World Bank, 2014. 
reinforced by the inequalities of opportunities and prolonged through the inequality spiral permanently capturing the workers' wellbeing through the decline of labour standards, earnings, and prospects. Accordingly, the principal focus of this study is placed on the earnings inequality which reflects the position of the majority of the population whose dependence on wages represents a matter of existence.

On the aforementioned foundations, this paper is addressing the central issue of Croatian pay inequalities and labour force standards with the hypothesis stating that the Croatian worker suffers both, from the worsening of their labour standards and from the high level of earning inequalities. The former is put to a test via research questions dealing with the labour share of income and labour productivity, overall net and gross pay inequality, between-county pay inequality, and between-sector pay inequality.

The secondary motivation for the study is to disclose that the inequality rise and the deterioration of the labour force position is at the root cause of Croatia's disastrous demographic trends. ${ }^{12}$ Given that the international migration is the symbol of inequality ${ }^{13}$ it is no surprise that Croatia is facing a high rate of emigration of skilled workers trying to capture Milanović's citizenship rent, trying to avoid Galbraith's national economic destiny, and seeking an economic refuge in a country with a higher level of social labour recognition. ${ }^{14}$

This research is structured in six parts. After the introduction, the author presents the literature overview within the second section. Section three elaborates on the methodology used and data induced limitations. Section four displays the results of the labour force position via functional income distribution and labour productivity. The fifth section presents the dimensions and trends of the overall, county-based, and sector-based pay inequities. Section six concludes.

\section{THE OVERVIEW OF THE CROATIAN ECONOMIC INEQUALITY}

Permeated with the momentous history ranging from Yugoslavia with a command economy and social ownership, through the independent country with a market economy and private property, to the European Union's single market, Croatia can serve as an ideal testing field for the investigation of the economic inequalities. The former is notably documented within the UTIP database, which is largely neglected within the existing research.

12 Akrap, A., Demografski slom Hrvatske: Hrvatska do 2051., Zagreb, Bogoslovna smotra, vol. $85,3 / 2015$, p. 855.

13 Black, R., Natali, C., Skinner, J., Migration and Inequality, background paper for the 2006 World Development Report, Sussex, 2004. Available at: www.worldbank.org.

14 Rubinić, I., Tajnikar, M., Labour Force Exploitation and Unequal Labour Exchange as the Root Cause of the Eurozone's Inequality, Zagreb, Društvena Istraživanja, vol. 28, 2/2019, p. 207. 
Figure 1. Croatian Estimated Household Income and Pay Inequality (1986-2015).

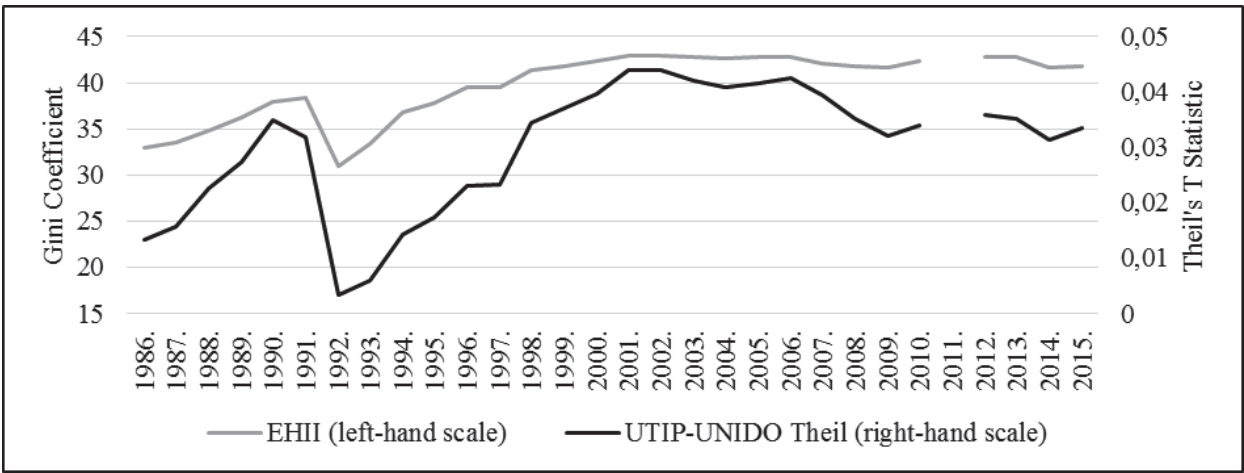

The UTIP ${ }^{15}$ database provides the UTIP-UNIDO industrial pay inequality data used for the calculation of the estimated household income inequality (EHII). The displayed patterns indisputably confirm the overall inequality rise and complement an existing explanation. In his work based on the household consumption survey, Nestic $^{16}$ concludes that the income inequality was declining from 1973-83, after which it started to rise until 1998. Nestić is rightfully surprised when writing that the inequality alterations were not high when comparing the socialist setting of 1988 to the market economy a decade later. The application of the mentioned dynamics to the presented figure builds upon the finding that the transition played a key role in the overall rise in inequality ${ }^{17}$ and indicate a significant inequality increase from 198898, suggesting that the consumption survey data are an inadequate estimator of the inequality during wartime.

Once this peculiar historical development is recognized, it becomes enigmatic that the Croatian case did not attract appropriate attention. From the modest body of comparative literature, the following works must be mentioned. The World Bank, ${ }^{18}$ in 2001, confirmed that the increasing inequality poses a severe challenge to the Croatian economy which suffers from a wide gap between the rich and the poor, high informal economy, inadequate safety nets, poor comparative performance, low competitiveness, and generally speaking, an unfavourable position. With the income inequality in question, Novokmet ${ }^{19}$ concludes that the transition to the market economy has raised the inequality measured through the usage of income tax data. The inequality stabilized in 1990 and was primarily driven by the rising shares of top earners. Novokmet proves that over one third of the incomes of the wealthiest

15 UTIP, Inequality Project Data-Set, Austin, University of Texas, 2018.

16 See Nestić, D., Ekonomske nejednakosti u Hrvatskoj 1973-1998, Zagreb, Financial Theory and Practice, vol. 26, 3/2002a, p. 595, and Nestić, D., Ekonomska nejadnakost u Hrvatskoj 1998. manja od očekivanja, Zagreb, Economic Review, vol. 53, 11-12/2002b, p. 27.

17 See Milanović, B., The Haves and the Have-nots, New York, Basic Books, 2012.

18 Croatia: Economic Vulnerability and Welfare Study, Washington, World Bank (Report No. 2079-HR), 2001.

19 Novokmet, F., Between communism and capitalism: essays on the evolution of income and wealth inequality in Eastern Europe 1890-2015, PhD Thesis, Paris School of Economics, 2017. 
Croatians comes from employment earnings. Thus, confirming the claim of Lakner and Atkinson and, as subsequent sections empirically show, confirming a vital role that top earners exercise in governing pay as well as overall inequality. In 1999, Milanovic ${ }^{20}$ finds that the crucial factor behind the upward trend during the transition is increased inequality of wage distribution, while Nestić ${ }^{21}$ confirms that the unequal wages are the biggest contributor to the overall inequality in Croatia.

From the pay inequality point of view, several authors ${ }^{22}$ have proven that the inequality is higher in the private sector than within the sectors with the prevailing country ownership. Sectoral and regional disparities were investigated by Nestic et al., ${ }^{23}$ who have shown that the employment loss from 2009-13 disproportionately affected low-wage sectors. They have, via the heterogenous counties' reliance on the minimum wage effects, effectively proven the between-county inequality and dependence. Additionally, the between-county pay inequality is confirmed by Karaman Aksentijević and Denona Bogović, ${ }^{24}$ while the growing tendency arising from diverging cross-county development levels is confirmed by Karaman Aksentijević and Ježić. ${ }^{25}$

An additional contribution came from Hofman et al. ${ }^{26}$ who, by examining Croatian wage inequality and differentials, proved the general inequality increase in the net earnings distribution. By building upon this research, Bićanić and Tuđa ${ }^{27}$ reported the continuation of the rising trend through 2013, and showed that the inequality was increasing within the expansion phase. The impact of the crisis 2007/2008 on the wage and income inequalities was investigated by Franičević, ${ }^{28}$ who displayed findings consistent with the ones presented in this paper. Franičević concluded that the inequalities have decreased from 2007-09 because the lower earners suffered high employment losses and the top earners experienced a decrease in wages. At the same

20 Milanović, B., Explaining the increase in inequality during transition, Economics of Transition, vol. 7, 2/1999, p. 299.

21 Nestić, D., The Determinants of Wages in Croatia, in: Proceedings of the $65^{\text {th }}$ Anniversary Conference of the Institute of Economics, Zagreb, Economic institute, 2005, p. 131.

22 e.g. Rubil, I., The Great Recession and Public-Private Wage Gap MPRA paper, No. 46798, Munich, 2013, and Nestić, D., Rubil, I., Tomić, I., Analysis of the Difference in Wages between the Public Sector, State-Owned Enterprises and the Private Sector in Croatia in the Period 20002012, Zagreb, Economic Trends and Economic Policy, vol. 24, 1/2015, p. 7.

23 Nestić, D., Babić, Z., Blažević Burić, S., Minimum age in Croatia: sectoral and regional perspectives, Economic Research, vol. 31, 1/2018, p. 1981.

24 Karaman Aksentijević, N., Denona Bogović, N., Economic Inequality and the Influence of Salaries on Income Inequality in the Republic of Croatia, Proceedings of Rijeka Faculty of Economics, vol. 21, 1/2003, p. 37.

25 Karaman Aksentijević, N., Ježić, Z., Tendencies of development inequalities of Croatian counties, Proceedings of Rijeka Faculty of Economics, vol. 29, 2/2011, p. 269.

26 Hofman, S., Bićanić, I., Vukoja, O., Wage inequality and labour market impact of economic transformation: Croatia 1970-2008, Economic Systems, vol. 36, 2/2012, p. 206.

27 Bićanić, I., Tuđa, D., Wage inequality in Croatia during boom and bust (2000-2014), In: Challenges of Europe: Growth, Competitiveness and Inequality, Hvar, University of Split, 2015.

28 Franičević, V., Croatia: Prolonged crisis with an uncertain ending, in: Vaughan-Whitehead, D. (ed.), Work Inequalities in the Crisis, Cheltenham, Edward Elgar Publishing Limited, 2011. 
time, the wages of the employed low earners exhibited rigidity due to the minimum wage impact, while the high crisis-led employment loss has increased the countries' poverty risk.

Lastly, the considerable advancement in the investigation of pay inequalities was done by Bićanić et al. ${ }^{29}$ These authors have set a foundation on which all future research in the field will build upon. Through a comprehensive approach, they have shown that the Croatian gross and net pay inequalities, generated by the high inequality in the distribution of the upper-tail earnings, are on the rise from the beginning of the 21 st century. Their study constitutes the basis upon which the author of this paper extends the analysis, provides a contribution, and solidifies the findings by elaborating them through the in-depth examination.

\section{MEASURING INEQUALITY FROM EARNINGS DATA}

For the pay inequality measurement, the author used Theil's T statistic founded on the works of Theil ${ }^{30}$ and widely used in the field of economic inequality. ${ }^{31}$ Theil's $\mathrm{T}$ statistic measures the degree of dispersion about the average value for groups of observations. Thus, for $n$ groups, Theil's T statistic is expressed as:

$$
T=\sum_{i=1}^{n}\left\{\left(\frac{p_{i}}{p}\right) *\left(\frac{y_{i}}{\mu}\right) * \log \left(\frac{y_{i}}{\mu}\right)\right\}
$$

where is the number of workers in group $i$, is the total working population, denotes the average income in group $i$, is the natural logarithm, and represents the average income of the total working population calculated as a weighted mean with weights being the population shares. The expression within the summation is called the Theil element. They are, as a consequence of the logarithmic term, positive for groups with above-average income and negative for groups with below-average income. However, the Theil's T statistic as the sum of elements is always positive. The practical feature of this measure is that it requires only information on distribution of workers and their earnings divided into mutually exclusive and completely exhaustive classes. $^{32}$

29 Bićanić, I., Ivanković, Ž., Kroflin, M., Nejednakost plaća u Hrvatskoj 2003.-2016, Zagreb, Politička misao, vol. 55, 3/2017, p. 43.

30 The Theil index is a member of the family of inequality measures entitled "general entropy measures" where the highly organized system is connected to the low-entropy, while highentropy is a sign of a disordered system. See Theil, H., Statistical Decomposition Analysis: With Applications in the Social and Administrative Sciences, Amsterdam, North-Holland, 1972.

31 See Conceição, P., Bradford, P., Galbraith, J., The Theil Index in Sequences of Nested and Hierarchical Grouping Structures, Eastern Economic Journal, vol. 27, 4/2001, p. 491; Sbardella, A., Pugliese, E., Pietronero, L., Economic development and wage inequality, PLOS One, vol. $12,9 / 2017$.

32 Conceição, P., Ferreira, P., The Young Person's Guide to the Theil Index, UTIP Working Paper, 14/2000. Available at: http://utip.gov.utexas.edu. 
The empirical inequality measurement is undergone using the CBS data collected for the purpose of investigating Croatian pay inequalities by Bićanić et al.

The study of overall net pay inequality uses the data on net earnings including the persons in employment in legal entities of all types of ownership working 160200 monthly hours. These data are gathered by the CBS through the Annual Survey on Persons in Employment and Paid-off Earnings from March (RAD-1G form). Data are collected on reports filled in by legal entities according to the records of persons in employment. The data are reporting the annual earning based on the information for March of each year and are distributed over twenty earning classes for the period of 2000-15. During the selected period there were some minor conceptual inconsistencies with regard to including/excluding the military and police within the analysis, alterations in national classification of economic activities in 2009, and alterations in the class size for the years 2014-15. The analysis of overall gross pay inequality uses data on gross earnings gathered by the CBS through the official forms R-sm for the years 2003-13 (collected by Central Registry for Insured Persons "Regos") and JOPPD form for 2014-15 (collected by Tax Administration). The gross earnings are including persons employed by legal entities for a definite or indefinite period of time, regardless of the duration of working hours. If the person employed receives gross earnings from multiple sources, they are treated as one by grouping the individual in the appropriate earnings class. The data on gross earnings are reported monthly from 2003-15 and are limited by following methodological issues: the JOPPD form gathers data more accurately than its preceding source, in certain years the data includes individuals in internship with special legal status, the dataset experienced class size alterations after 2007 (from 83 classes in 2007 to 164 classes from 2008 onwards), the data set has one misreported period (December, 2013) omitted within this analysis.

Since these sources report a categorical earning measurement, by grouping individuals into earning classes, all the observations within an interval are assigned the same value. The conversion of group data to point data is performed via midpoint method imputing the midpoint interval value to each observation within the class. The earnings of the highest, open-ended category, are received by following the commonly used approach, ${ }^{33}$ which assumes that the midpoint exceeds the open interval lower bound by $10 \%$.

The Croatian between-county pay inequality is based on the annual average data on monthly net and gross earnings and the number of persons in employment, which are publicly available and published by $\mathrm{CBS} .{ }^{34}$ The persons in employment are those employed for a fixed or specified period of time, irrespective of whether they work full time or less. The data are reporting the average earnings for twenty-one counties gathered from the annual survey from 1998-15 with a reporting date of 31 March.

33 See Fields, G. S., A Compendium of Data on Inequality and Poverty for the Developing World, New York, Cornell University, 1989, Von Fintel, D., Earnings bracket obstacles in household surveys - How sharp are the tools in the shed?, Stellenbosch Economic Working Paper, 08/2006; $\mathrm{Yu}, \mathrm{D}$., Some factors influencing the comparability and reliability of poverty estimates across household surveys, Stellenbosch Economic Working Paper, 03/2013.

34 CBS, Employments and Wages Review by Counties. Available at: www.dsz.hr (Accessed November 7, 2018). 
Between-sector pay inequality is measured through the dispersion over nineteen national-level activities by accounting for annual average net and gross monthly paid off earning in addition to the number and composition of persons in paid employment in legal entities. The data are gathered from the survey including legal entities of all types of ownership and covering $70 \%$ of the persons in employment, and are collected on reports filled-in by legal entities according to the records of persons in employment. All the data are publicly available and retrieved from $\mathrm{CBS}^{35}$ for the period of 2000-15.

When empirically employed, specified methodological restrictions combined with data limitations generate constraints that one must be aware of when making final judgments. The irreversible data defects are the unfortunate reality affecting a majority of the works in the field, or as Galbraith puts it: "If science consists in a search for patterns in data, then the study of economic inequality suffers from an original sin" $" 36$. On the bright side, the concerns raised by the data imperfections will be countervailable when a higher number of high-quality micro data observations (JOPPD form) will enhance the economic inequality analysis.

\section{LABOUR SHARE OF OUTPUT AND PRODUCTIVITY}

The functional income distribution and accompanying, regulating laws have long been recognized as the principal problems in political economy. ${ }^{37}$ According to Atkinson, ${ }^{38}$ the income breakdown by its sources provides a valuable starting point in understanding the distribution of income inequality and addressing the concern with regards to social justification of distinct income sources. It is on these grounds that the indispensable inquiry into the labour force position must commence by investigating the dynamics of the labour share of income. In order to capture and analyse the wellbeing of the Croatian labour force, the point of departure lays in the disintegration of the national income. For this purpose, the author calculated the labour share through the method treating the labour share of income () as the ratio of the total employees' remuneration to the value added. ${ }^{39}$ Formally,

(2)

$$
L S=\frac{C O E}{G D P-T_{\text {ind }}-C F C}
$$

35 CBS, MSI Employment and Wages. Available at: www.dsz.hr [Accessed November 7, 2018].

36 Galbraith, J. K., Inequality, unemployment and growth: New measures for old controversies", Journal of Economic Inequality, vol. 7, 2/2009, p. 190.

37 See Ricardo, D., Principles of Political Economy and Taxation, London, Dent, 1911.

38 Atkinson, A. B., Factor shares: the principal problem of political economy?, Oxford Review of Economic Policy, vol. 25, 1/2009, p. 3.

39 See Jayadev, A., Capital account openness and the labour share of income, Cambridge Journal of Economics, vol. 31, 3/2007, p. 423; Daudey, E., Garcia-Penalosa, C., The Personal and the Factor Distributions of Income in a Cross-Section of Countries, Journal of Development Studies, vol. 43, 5/2007, p. 812. 
where $\mathrm{COE}$ is the compensation for employees, GDP is the gross domestic product or the value added, $\mathrm{T}_{\text {ind }}$ denotes indirect taxes less subsidies, and $\mathrm{CFC}$ is the consumption of fixed capital.

It must be noted that the, in line with Guerriero ${ }^{40}$ and Bernanke \& Gürkaynak, ${ }^{41}$ LS was calculated by using GDP. That being said, it should be emphasised that the modern economic relationships pose a challenge in differentiating between income sources resulting in an inadequate labour share estimation. The latter is explained by Guerriero and, as such, is beyond the scope of this paper. However, by acknowledging all computational methods, the choice to use the presented one is the outcome of the fact that the usage of the $\mathrm{COE}$ is most convenient for the comparisons with the subsequent sections, as well as the fact that other methods, with analogous patterns, overestimated the labour share by sometimes reporting the value greater than 1 .

In order to investigate the full extent of the labour force position and gain a broader understanding of the matter, aside from the labour share, the research must encompass the labour force productivity. Such an upgrade is useful for questioning whether the productivity movement is commensurate with the income received by the respective production factor. Amongst a variety of productivity quantification approaches, the author applied the frequently used, nominal labour productivity per person employed, expressing the productivity as the ratio of labour inputs to the value of production. Quantifying the productivity as the GDP per employed was preferred because it points out the general productivity impression and enables for the calculation of the longest period attainable.

On this basis, the two abovementioned components were calculated for Croatia. The data for the COE, GDP and $\mathrm{T}_{\text {ind }}$ is retrieved from Eurostat. ${ }^{42}$ The number of employed is taken from ILO, ${ }^{43}$ and the CFCO data is obtained from Eurostat ${ }^{44}$ by estimating the missing values through the usage of CBS' ${ }^{45}$ information on the share of CFC in GDP.

40 Guerriero, M., The Labour Share of Income around the World, Development Economics and Public Policy Working Paper, 32/2012.

41 Bernanke, B. S., Gürkaynak, R. S., Is Growth Exogenous? Taking Mankiw, Romer, and Weil Seriously, in: Bernanke, B.S., Rogoff, K. (ed.), NBER Macroeconomics Annual 16, Cambridge, MIT Press, 2002.

42 Eurostat, GDP and main components. Available at: http://ec.europa.eu [Accessed October 8, 2018].

43 ILO, Status in employment - ILO modelled estimates. Available at: http://www.ilo.org [Accessed October 8, 2018].

44 Eurostat, GDP and main aggregates. Available at: http://ec.europa.eu [Accessed October 8, 2018].

45 CBS, Annual Gross Domestic Product,1995-2005, Zagreb, CBS (First Release No. 12.1.3.), 2009. 
Figure 2. Labour share of GDP and labour productivity (1999-2015).

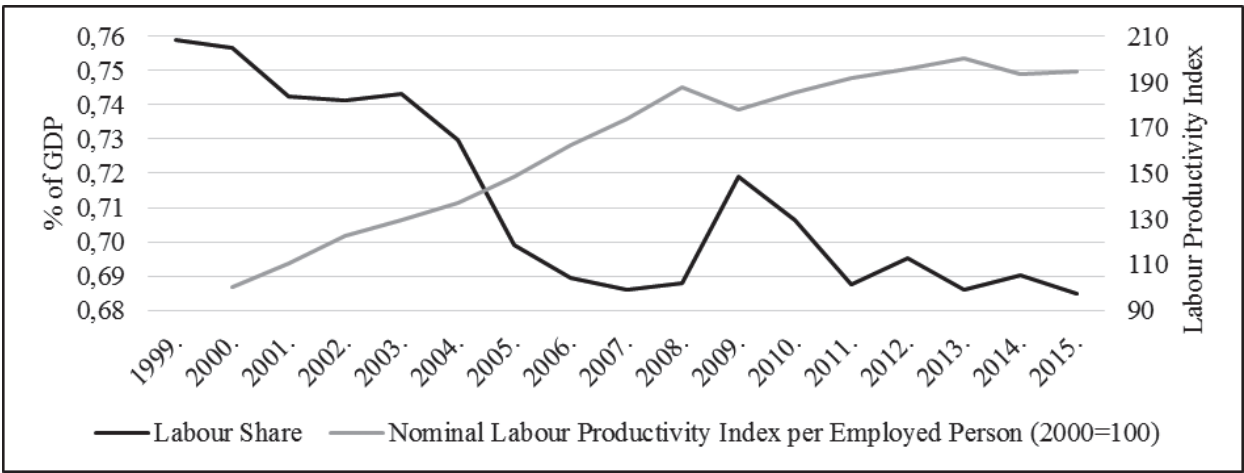

As demonstrated, founded on the author's calculations based on the data from Eurostat, CBS, and ILO, within the analysed period, the position of the Croatian labour force substantially deteriorated as a result of two reinforcing tendencies. Firstly, the share of the national income going to the labour force reported a 10\% drop in 2015 in comparison to the beginning of the period. Secondly, the falling labour standard was further intensified with $95 \%$ increase in the labour productivity in 2015 compared to 2000 .

This necessitates a digression. Considering that the factor shares are relative values, what appears to be a 2008 labour position improvement is a consequence of the crisis-led decline in the profit income share. This brings to the surface the ultimate degree of the labour position worsening, becoming apparent as soon as the analysis is broadened to include profits. The profit share, calculated from the same source and encompassing the gross sum of operating surplus and mixed income, net of fixed capital consumption, reported a $28 \%$ rise within the same period. Paradoxically, this inequality is further enhanced by the Croatian tax system, through the violation of the equity principles and unfair taxation that disproportionally affects the labour earnings ${ }^{46}$ Effectively, the Croatian worker that bears a higher tax burden experienced a relative decline in their gross, pre-tax earnings (COE) alongside the rise of their productivity and simultaneously with the growth of the share of national income constituting profits.

\section{DIMENSIONS AND DYNAMICS OF CROATIAN PAY INEQUALITY}

The scrutinization of the pay inequality phenomena is carried out through two major segments distinguished by the nature of inquiry and data used. The first segment deals with the dynamics and implications of overall pay inequality, analysed via micro data on earnings distribution. The second segment deals with the specific

46 See Škalamera-Alilović, D., Rubinić, I., The Tax System as a Generator of Economic Inequality in Croatia. In: Book of Proceedings: $16^{\text {th }}$ International Scientific Conference on Economic and Social Development, Varaždin, Development and Entrepreneurship Agency, 2016; p. 459. 
pay inequality dimensions accomplished through the annual average data. The interconnectedness of presented components will broaden the understanding of the researched topic and demonstrate new findings with respect to Croatian inequality.

The overall inequality analysis, constituting the first segment, is subdivided into two parts differentiating amongst pay inequalities based on the earning status. The first component investigates the net inequality, while the second one deals with the gross inequality. Due to the usage of various data and grouping sizes, the aforementioned components are not comparable and must be investigated independently.

Figure 3. Overall net pay inequality (2000-2015)

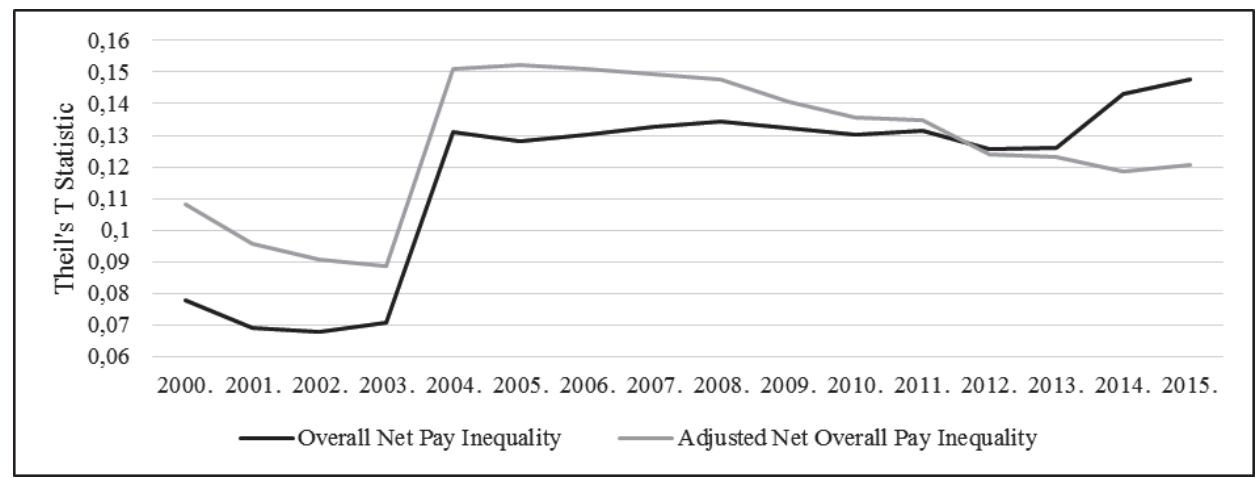

Within Figure 3, overall pay inequality is retrieved from Bićanić et al., whereas adjusted overall pay inequality is the author's calculation based on CBS data (RAD-1G form). Overall net pay inequality occurs in two forms based on the distinct approach taken by the authors. The main difference arises as a consequence of methodological changes in the raw data connected primarily with the series break in the size/span of the earning classes. While Bićanić et al. presented the overall inequality trend derived from twenty classes without class alteration, the author of this paper demonstrated the adjusted version comprised of class synchronization and exhibiting the trend with a reduced number of classes (sixteen). Due to the unequal class composition, the results obtained are not directly comparable. Regardless of technical disparities, it is evident that both methods indicate a trend marked by a radical rise during 2003, after which the inequality was maintained on a high level. To put trends into perspective, during the reference period, the number of representatives within the class earning above 21,000 HRK increased by $1278 \%$ from $2000-15$, while the dramatic rise in 2003 came as a consequence of a $69 \%$ rise in representatives earning less than $2200 \mathrm{HRK}$, with a $17 \%$ rise of the highest earning representatives.

The adjusted trend seems to be more consistent with the underlying theoretical interpretation suggesting the influence of economic cycles within the inequality patterns. This cyclical influence is captured within the inequality decline initiated by the economic downturn of 2008 lasting until 2014. At this point, it bears mentioning that the analysis is limited to the pay inequality structure, and that without further investigation, generating conclusions about seemingly positive trends can be 
misleading. Therefore, it is of paramount importance to explain that this inequality decline is not a consequence of benevolent economic forces as indicated in the subsequent figure.

Figure 4. Employment structure for selected classes expressed in thousands of employed (2000-2015).

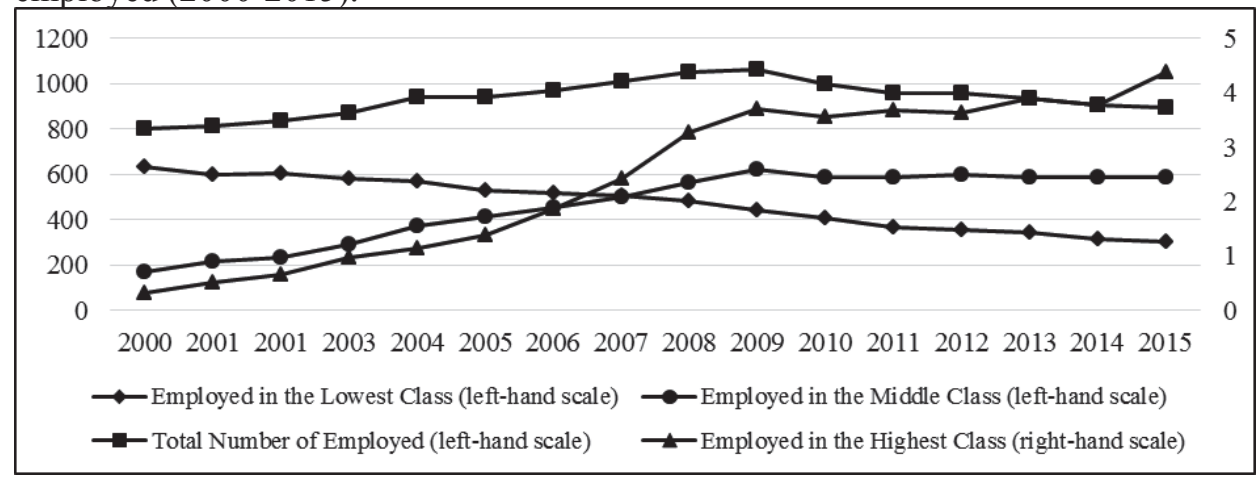

Figure 4 displays author's calculation based on CBS data (RAD-1G form) that shows the total number employed, employed in the lowest class (earning up to 4,000 HRK), employed in the middle class (earning between 4,001-21,000 HRK), and employed in the highest earning class (earning above 21,001 HRK). Accordingly, it becomes evident that the decline in the pay inequality comes as a result of the dynamics occurring within the lower tail of the earning distribution. Inflicted by the crisis, the drop in the total number employed occurred through the decline of employment in the lowest earning class while the trends for middle and high earners experienced a high level of stabilisation. This implies that the surge in unemployment induced by the crisis was the outcome of laying off of the low earning workers. Therefore, the decline of the adjusted overall net pay inequality from Figure 3 did not improve the wellbeing of the average worker since it happened as the manifestation of the massive layoffs which increased overall Croatian economic inequality.

Acknowledging these findings brings about uncertainty and negative perspectives when contemplating on the future of Croatian pay inequality. Derived from the notion that the European double dip recession ended in 2013, the challenge that the policymakers should be increasingly focused on is how to prevent the corresponding re-appearance of the inequality increase that occurred within the last expansion period.

Alternatively, the research question is studied from the aspect of gross earnings. 
Figure 5. Overall gross pay inequality (2003-2015).

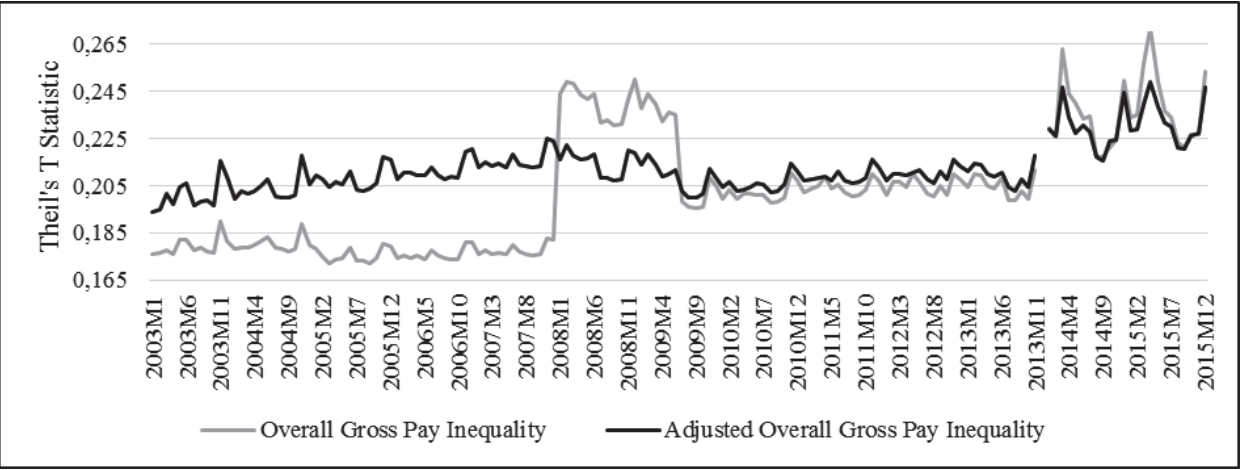

In a manner similar to that of net inequality, Figure 4 presents two gross inequality trends. The overall pay inequality is retrieved from Bićanić et al., whereas adjusted overall pay inequality is the author's calculation based on Regos and Tax Administration data (R-sm and JOPPD forms). Again, the difference arises from the break in the raw data methodology which, up to 2007, reports earnings grouped into 83 classes, while from 2008 onwards that number rises to 164 . The overall gross pay inequality is computed with original class composition, while the adjusted trend is author's calculation through the application of the uniform number of earning classes throughout the period. The corrected version thus synchronizes the classes by the total distribution disaggregation over 83 classes. Additionally, in order to minimize the consequential loss of information inflicted by the class reduction, the average earning of the highest class was estimated as an average annual earning of the upper 84 classes (earning more than 41,000 HRK) reported for the period of 2008-15. As depicted, the adjusted version exhibits a smoother trend and repeatedly captures the cyclical influence known from the economic theory. These mostly overlapping methods are drawing corresponding conclusions and unambiguously prove the increasing tendency of Croatian gross pay inequality amounting to a $27 \%$ increase over the period of twelve consecutive years.

An attractive feature of investigating the gross inequality via monthly data surfaces from its ability to be related to the conventional earnings data. This allows for the straightforward investigation of the inequality drivers, a scenario which is particularly interesting to associate with the ratio between minimum and average gross wage. 
Figure 6. The share of minimum gross wage in the average gross wage (2003-15).

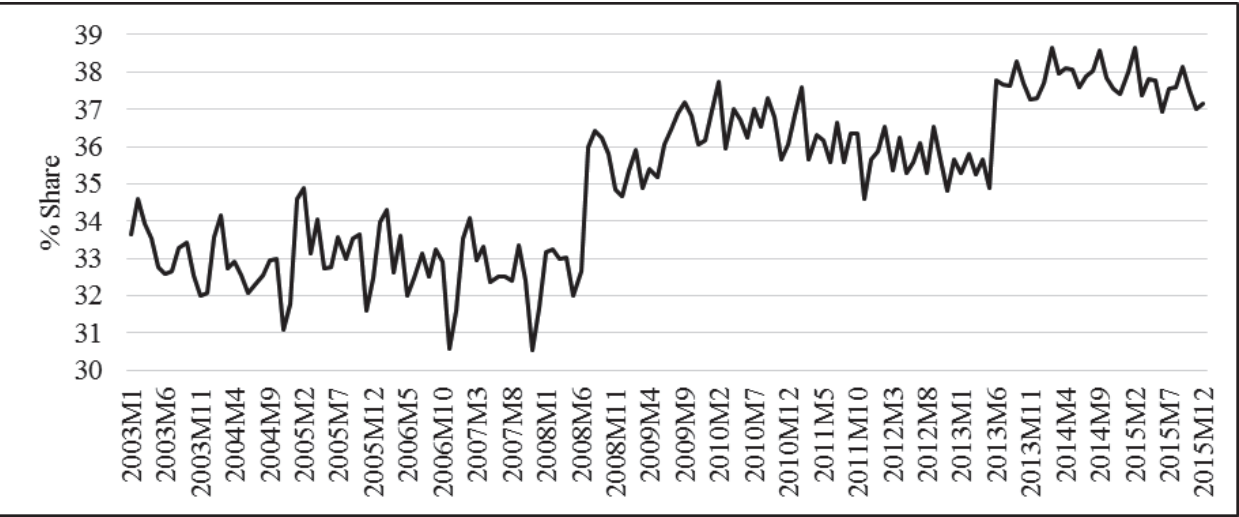

Based on the data retrieved from $\mathrm{ZDOO},{ }^{47} \mathrm{ZMP},{ }^{48}$ and $\mathrm{CBS}$, the recognition of the continuously increasing trend of the share of minimum wage in the average gross wage comes as an unexpected outcome. Given the gross pay inequality growth, it is reasonable to anticipate that the lower earning representatives would experience a worsening rather than improvement of their relative position. The intuitive response to such insight is to direct the study to the upper tail of the earnings distribution.

Figure 7. Percentage share of the number of employed in total number employed for the selected classes (2003-2015).

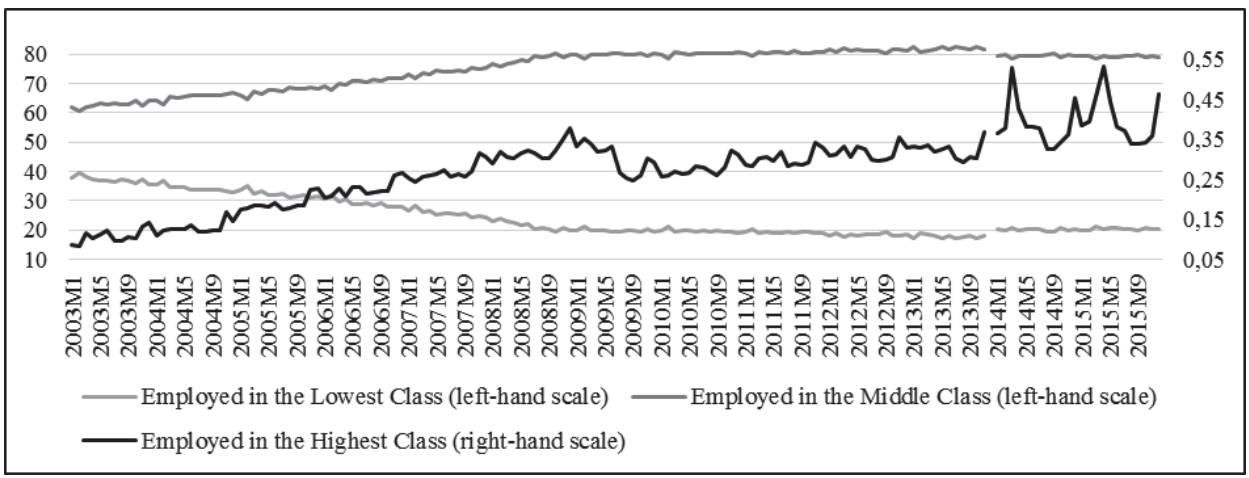

Since the quantification of the Croatian gross pay inequality is undergone using the Theil index, the influence of certain classes can simply be viewed through the number of its representatives expressed as the share of total employed. With this in mind, based on the data from Regos and Tax Administration (R-sm and JOPPD forms), all workers covered by the data are clustered into three earning brackets. The lower tail includes the workers earning up to 3,500 HRK, the middle bracket 
includes employees earning 3,500-41,000 HRK, and the upper tail is comprised of the wealthiest individuals with more than $41,000 \mathrm{HRK}$ in gross monthly earnings. At this point, it becomes indisputable not only that the adjusted overall gross pay inequality is highly and positively correlated with the number of upper tail individuals (.798), but also that the inequality growth is predominantly driven by the rise of high earners. This notion becomes especially alarming when it is considered that the absolute number of high earners in December 2015 increased by 543\% since the beginning of the period. Moreover, while the lowest and middle classes reported mostly balanced trends, the movement of the high earners suggests, in accordance with previous findings, the presence of a cyclical influence. The full extent of the issue becomes striking when it is confirmed that, on average, in $201520 \%$ of the total Croatian workforce earned less than 3,500 HRK, 5,211 individuals earned more than 41,000 HRK, 660 earned more than 100,000 HRK, and 28 earned more than 500,000 HRK, in gross monthly earnings. The acknowledgment that the individual earning minimum wage must work at least 13.7 years to earn as much as the highest earner makes in a month, defies the logic of marginal contribution and the common-sense justification. ${ }^{49}$

Upon exhibiting the findings related to inequality dynamics, the forthcoming section is addressing the issue of dimensions in which existing pay inequalities manifest. This is achieved by considering the matter from two distinct aspects, constituting the second major segment.

Figure 8. Between-county pay inequality (1998-2015).

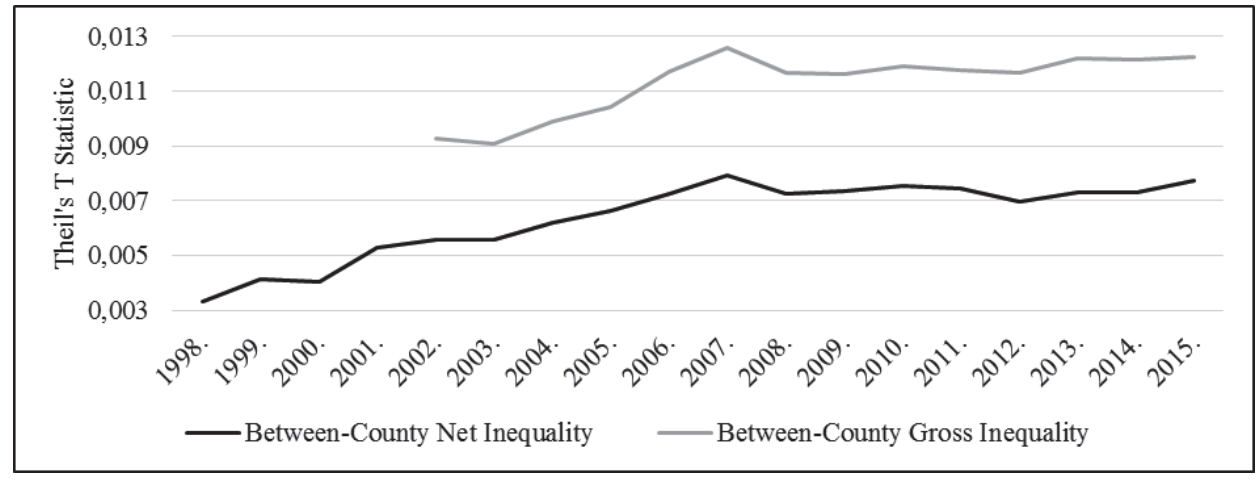

Based on the author's calculation derived from the CBS data, the analysis has reported a steadily increasing pay inequality trend. From the beginning of the investigated period in 2015 , the net inequality has increased by $146 \%$ while the gross inequality has risen by $31 \%$. Regardless of the earning status, throughout the period, receiving the highest average earning was an exclusive privilege of the employed within the City of Zagreb. Contrarily, the lowest average earnings were reported within Međimurje and Varaždin counties. If pay inequality is analyzed via Theil elements, the group with the lowest earnings includes Osijek-Baranja and Varaždin

49 In the case of net wages calculated for December 2015, for individuals with basic personal deductions reported in City of Zagreb, this difference is at least nine years. 
counties. Conversely, the group with above-average earnings, after 2007 includes the City of Zagreb in addition to Primorje-Gorski kotar (until 2014) and DubrovnikNeretva (2014-15), which reported positive net values. When it comes to the ratio between an average county's earnings and the average country's earnings (weighted by the counties' respective population shares), there exists variation in the earning status. Therefore, the above-average gross earnings were measured in: the City of Zagreb (2002-15), Primorje-Gorski kotar (2006-06; 2008), Istria (2002-06), and Lika-Senj (2003). Whereas, above-average net earnings were reported in: the City of Zagreb (1998-15), Primorje-Gorski kotar (1998-14), Zadar (1998-99; 2003-05), Split-Dalmatia (1999-01), Sisak-Moslavina (2000), Istria (2001-07), and DubrovnikNeretva (2014-15). Given that the average earnings of those employed in the Croatian capital, the City of Zagreb, on average, surpassed national levels by $22 \%$ (gross) or $16 \%$ (net), the results provide a clear insight into the extent that the centralization process has regarding governance of Croatia's overall economic inequality.

Compared to the gross, the lower net between-county pay inequality can be largely attributed to the national taxation policies. However, given the shrinking number of counties with above-average earnings, the effectiveness of these policies is undeniably diminishing, irrespective of the introduction of a local surtax on income tax in 2001. These striking patterns suggests that the geographical location of the employment is becoming a determinant of workers' wellbeing, perhaps to a higher degree than the skills that workers have to offer. Accordingly, it is no surprise, especially in recent times, that the Croatian workers tend to identify themselves and their economic position by where they live.

What is particularly interesting, in this hitherto analysis, is that the Croatian pay inequality is negatively correlated with the unemployment rate published by Eurostat. $^{50}$ Such a dynamic opposes Galbraith ${ }^{51}$ and reveals the unconventional cyclical influence on inequality. It remains a puzzle why the pay inequality increased in the expansion phase and decreased in the contraction phase of the economic cycle. At the time of writing this paper, based on the data availability, the partial intuitive interpretation is that the inequalities in the pay structures are extremely dependent on the procyclical, upper tail movements. This insinuates that the top earners have a much higher effect on the entire pay inequality than the lower and middle part of the distribution combined. Regardless of the gravity of the remark, this issue deserves special attention and must be examined in the forthcoming research.

The closing type of pay inequality within the realm of this paper deals with sectoral pay differentials. Albeit less polarized than in the between-county, the between-sector component plays a paramount role in creating pay inequality.

50 Eurostat, Unemployment by sex and age - annual average, available at: http://ec.europa.eu [Accessed January 9, 2019].

51 Galbraith, J. K., Inequality and Instability, New York, Oxford University Press, 2012. 
Figure 9. Between-sector pay inequality (2000-2015).

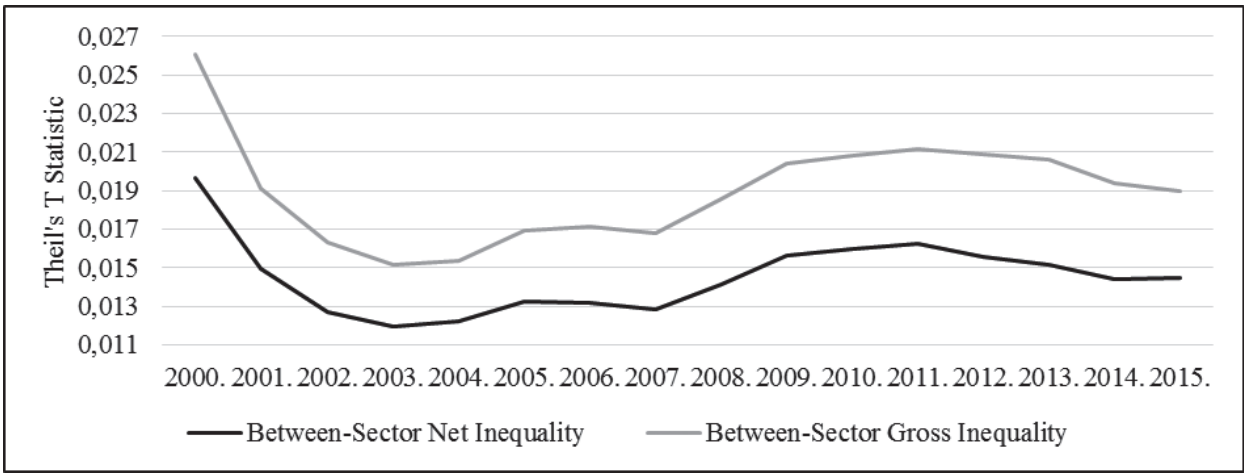

Based on the author's calculation derived from the CBS data, the deviation between higher gross and lower net levels, observable within Figure 6, is equivalently present in the current instance. In the case of between-county inequality, some counties reported below-average gross earnings and above-average net earnings. This was not the occurrence with the components of the sector analysis. In the latter case all activities predominantly retained their position regardless of the earning status. ${ }^{52}$ The lack of activity redistribution is a straightforward consequence of non-existing taxation policies targeting the individual activities in the same way as the local surtax on income tax (to an extent), remedying the geographical pay inequalities. The author will elaborate the between-sector pay inequalities by focusing on the final year covered by the research. In 2015, there were nine activities with above-average earning levels that contributed to the inequality. Starting with the sector having the highest contribution, these activities are: professional, scientific and technical, financial and insurance, information and communication, human health and social work, transportation and storage, public administration and defence, mining and quarrying, and other activities. On the other side of the spectrum, ten activities remained, amongst which the worst outcome was measured in manufacturing, wholesale, and retail activities. One last notion bears mentioning. From the presented trend, one might conclude that the between-sector pay inequality is of lesser significance to the overall inequality than the between-county inequality, however this is not the case. The latter claim can be justified by deeper insight into average gross earnings for the period between 2002-15. The lowest county's earning is 5,511 HRK while the highest is 8,682 HRK, resulting in a range of 3,171 HRK. In the sectoral case, the results are 4,782 HRK for the lowest earning, 10,961 HRK for the highest earning, and 6,178 HRK for their respective range. Given that the sectoral range exceeds that of counties almost twice over, this extreme difference is confirmation of the importance that the between-sector pay inequality plays in terms of, not solely overall pay inequality, but total Croatian economic inequality as well.

52 A minor deviation occurred between 2008-10 when education activity changed the belowaverage gross values for above-average net values. In 2003, an equivalent practice took place with regards to water supply, sewerage, waste management, and remediation activities. 
Due to the high and rising levels of overall pay inequalities, an increasing number of individuals in the highest earning tier, continuously growing between-county inequality, and high levels of between-sector pay inequality, it is safe to conclude that economic inequality is a viable threat deteriorating the wellbeing of the majority of Croatian workers at the expense of those at the top. The former holds especially if the analysis is extended to include categorical inequalities remaining outside of the context of this paper, as well as income and wealth inequality which are historically proven to be far greater generators of economic inequality when comparing them to the pay inequalities.

\section{CONCLUSION AND DISCUSSION}

In this paper, the author argued that the principal problem confronting the Croatian worker's wellbeing is a cumulative consequence of two detrimental tendencies that worsen the labour standards and increase inequalities. The empirical analysis confirmed that the Croatian worker experienced a relative decline of their gross pre-tax earnings while substantially increasing productivity. This occurred alongside the growing profit share of income, simultaneously with the unequal taxation disproportionately affecting the labour, and concurrently with the unfavourable pay inequalities. The study has shown that net pay inequality is high and likely to rise. Furthermore, when the net inequality declined, it did so by laying-off the representatives of the lowest earning classes, i.e. by increasing the overall economic inequality. The gross inequality exhibited continuous rise highly and positively correlated with the earnings distribution's upper tail being increasingly concentrated within the wealthiest fraction of society. The upward between-county pay inequality, as an outcome of the longlasting centralization process, divided the workers based on geographical grounds by favouring the City of Zagreb as the exclusive county consistently reporting aboveaverage values. Finally, the between-sector pay inequality indicated a high and stable trend with a range between the highest-lowest paying sector surpassing its betweencounty counterpart approximately twice over.

Once confirmed, this state of affairs becomes more perplexing when combined with interdependent inequality sources. Therefore, the formation of the concluding judgements must account for highly concentrated inequalities of wealth and income, as well as categorical inequalities and inequalities of opportunity. Consequently, it is evident that these inequalities are the leading cause of Croatia's human capital outflow and therefore, must be mitigated.

With this in mind, it is unquestionable whether the central place should be reserved for the relative enhancement of the distribution's lower tail. Among a variety of policy recommendations, the following must be singled out. The minimum wage should be increased to commensurate with rising prices and a part of the rising productivity. Indexing the minimum wage to the median wage is worthy of attention because it would incentivize employers to invest in their workers' productivity simultaneously while lifting the standards of the poorest. The tax code must be more progressive to account for a country's role as a protector of the private property. Last but not 
the least, the national policymakers need to implement a periodical taxation of the highest earnings and wealth. The latter is a prerequisite for maintaining the minimum wellbeing of those in need during the recession where the collected revenues would serve as a safety net through the increase in transfers and social security spending. This would prevent the ominous effects, as seen during the last crisis where the decrease in pay inequality occurred through the firing of the expendable (low earning) workers.

Given that until 2019, policymakers failed to implement a positive set of measures and even decreased the tax code's progressiveness, the future is not promising. In their defence, it must be noted that the adjustments proposed in the Theory of the Second Best imply government intervention. Therefore, attaining the optimal performance via remedying for the inequalities as market failures is a delicate matter since it encompasses the trade-offs between the economic incentives and redistribution. Consequently, the national policymakers, conditioned by the free market, low competitiveness, and capital scarcity, are limited in attempts to respond to the negative pressures intensified by the globalisation.

The findings presented within this study can serve as a platform for the inquiry directed toward including for the overlooked inequality sources. This research must be utilized as the foundation for the future investigations into the Croatian inequality phenomena, where the ultimate challenge is being posed by the antagonism between the low-competitive national social state and globalization. Special attention should be placed on the investigation of Croatian fiscal policy with regards to its contribution in the formation of persisting inequalities. The sphere of taxation where the policymakers must innovate and implement adequate solutions to increase the average citizens' welfare remains to be investigated. The establishment of control upon the abovementioned adverse trends, via redefinition of the current, sub-optimal policies, must become a societal imperative that will overcome ominous demographic trends and create the foundation for economic prosperity.

\section{BIBLIOGRAPHY}

1. Akrap, Anđelko, Demografski slom Hrvatske: Hrvatska do 2051., Zagreb, Bogoslovna smotra, vol. 85, 3/2015, pp. 855-868.

2. Atkinson, Anthony Barnes, Factor shares: the principal problem of political economy?, Oxford Review of Economic Policy, vol. 25, 1/2009, pp. 3-16.

3. Bernanke, Ben Shalom, Gürkaynak, Refet Soykan, Is Growth Exogenous? Taking Mankiw, Romer, and Weil Seriously, in: Bernanke, B.S., Rogoff, K. (eds), NBER Macroeconomics Annual 16, Cambridge, MIT Press, 2002.

4. Bićanić, Ivo, Ivanković, Željko, Kroflin, Matija, Nejednakost plaća u Hrvatskoj 2003.2016, Zagreb, Politička misao, vol. 55, 3/2017, pp. 43-81.

5. Bićanić, Ivo, Tuđa, Dora, Wage inequality in Croatia during boom and bust (2000-2014), in: Challenges of Europe: Growth, Competitiveness and Inequality, Hvar, University of Split, 2015.

6. Black, Richard, Natali, Claudia, Skinner, Jessica, Migration and Inequality, background paper for the 2006 World Development Report, Sussex, 2004. Available at: www. worldbank.org. 
7. CBS, Annual Gross Domestic Product,1995-2005, Zagreb, CBS (First Release No. 12.1.3.), 2009.

8. CBS, Employments and Wages Review by Counties. Available at: www.dsz.hr [Accessed November 7, 2018].

9. CBS, MSI Employment and Wages. Available at: www.dsz.hr [Accessed November 7, 2018].

10. Conceição, Pedro, Bradford, Peter, Galbraith, James Kenneth, The Theil Index in Sequences of Nested and Hierarchical Grouping Structures, Eastern Economic Journal, vol. 27, 4/2001, pp. 491-514.

11. Conceição, Pedro, Ferreira, Pedro, The Young Person's Guide to the Theil Index, UTIP Working Paper, 14/2000. Available at: http://utip.gov.utexas.edu.

12. Conrad, Edward, The Upside of Inequality, New York, Penguin Random House, 2016.

13. Daudey, Emilie, Garcia-Penalosa, Cecilia, The Personal and the Factor Distributions of Income in a Cross-Section of Countries, Journal of Development Studies, vol. 43, 5/2007, pp. 812-829.

14. Eurostat, GDP and main aggregates. Available at: http://ec.europa.eu [Accessed October 8, 2018].

15. Eurostat, GDP and main components. Available at: http://ec.europa.eu [Accessed October 8, 2018].

16. Eurostat, Unemployment by sex and age - annual average. Available at: http://ec.europa. eu [Accessed January 9, 2019].

17. Fields, Gary Sheldon, A Compendium of Data on Inequality and Poverty for the Developing World, New York, Cornell University, 1989.

18. Franičević, Vojmir, Croatia: Prolonged crisis with an uncertain ending, In VaughanWhitehead, D. (ed.), Work Inequalities in the Crisis, Cheltenham, Edward Elgar Publishing Limited, 2011.

19. Friedman, Milton, Friedman, Rose, Free to Choose, New York, Harcourt, 1980.

20. Galbraith, James Kenneth, Created Unequal, Chicago, Chicago University Press, 2000.

21. Galbraith, James Kenneth, Inequality and Instability, New York, Oxford University Press, 2012.

22. Galbraith, James Kenneth, Inequality, New York, Oxford University Press, 2016.

23. Galbraith, James Kenneth, Inequality, unemployment and growth: New measures for old controversies", Journal of Economic Inequality, vol. 7, 2/2009, pp. 189-206.

24. Guerriero, Marta, The Labour Share of Income around the World, Development Economics and Public Policy Working Paper, 32/2012.

25. Hoffman, Saul, Bićanić, Ivo, Vukoja, Oriana, Wage inequality and labour market impact of economic transformation: Croatia 1970-2008, Economic Systems, Vol. 36, 2/2012, pp. 206-217.

26. ILO, Status in employment - ILO modelled estimates. Available at: http://www.ilo.org [Accessed October 8, 2018].

27. Jayadev, Arjun, Capital account openness and the labour share of income, Cambridge Journal of Economics, vol. 31, 3/2007, pp. 423-443.

28. Karaman Aksentijević, Nada, Denona Bogović, Nada, Economic Inequality and the Influence of Salaries on Income Inequality in the Republic of Croatia, Proceedings of Rijeka Faculty of Economics, vol. 21, 1/2003, pp. 37-51.

29. Karaman Aksentijević, Nada, Ježić, Zoran, Tendencies of development inequalities of Croatian counties, Proceedings of Rijeka Faculty of Economics, vol. 29, 2/2011, pp. 269290.

30. Lakner, Christoph, Atkinson, Anthony Barnes, Wages, Capital and Top Incomes: The Factor Income Composition of Top Incomes in the USA, 1960-2005, 2014. Available at: www.ecinq.org. 
31. Mankiw, Gregory Nicholas, Defending the One Percent, Journal of Economic Perspectives, vol. 27, 3/2013, pp. 21-34.

32. Milanović, Branko, Explaining the increase in inequality during transition, Economics of Transition, vol. 7, 2/1999, pp. 299-341.

33. Milanović, Branko, Global Inequality, London, Harvard University Press, 2016.

34. Milanović, Branko, The Haves and the Have-nots, New York, Basic Books, 2012.

35. Nestić, Danijel, Babić, Zdenko, Blažević Burić, Sanja, Minimum age in Croatia: sectoral and regional perspectives, Economic Research, vol. 31, 1/2018, pp. 1-30.

36. Nestić, Danijel, Ekonomska nejadnakost u Hrvatskoj 1998. manja od očekivanja, Zagreb, Economic Review, vol. 53, 11-12/2002b, pp. 1109-1150.

37. Nestić, Danijel, Ekonomske nejednakosti u Hrvatskoj 1973-1998, Zagreb, Financial Theory and Practice, vol. 26, 3/2002a, pp. 595-613.

38. Nestić, Danijel, Rubil, Ivica, Tomić, Iva, Analysis of the Difference in Wages between the Public Sector, State-Owned Enterprises and the Private Sector in Croatia in the Period 2000-2012, Zagreb, Economic Trends and Economic Policy, vol. 24, 1/2015, pp. 7-51.

39. Nestić, Danijel, The Determinants of Wages in Croatia, in: Proceedings of the $65^{\text {th }}$ Anniversary Conference of the Institute of Economics, Zagreb, Economic institute, 2005, pp. 131-162.

40. Novokmet, Filip, Between communism and capitalism: essays on the evolution of income and wealth inequality in Eastern Europe 1890-2015, PhD Thesis, Paris School of Economics, 2017.

41. Piketty, Thomas, Capital in the Twenty-First Century, London, Harvard University Press, 2014.

42. Piketty, Thomas, The Economics of Inequality, London, Harvard University Press, 2015.

43. Ricardo, David, Principles of Political Economy and Taxation, London, Dent, 1911.

44. Rubil, Ivica, The Great Recession and Public-Private Wage Gap MPRA paper, No. 46798, Munich, 2013.

45. Rubinić, Ivan, Tajnikar, Maks, Labour Force Exploitation and Unequal Labour Exchange as the Root Cause of the Eurozone's Inequality, Zagreb, Društvena Istraživanja, vol. 28, 2/2019, pp. 207-228.

46. Sbardella, Angelica, Pugliese, Emanuele, Pietronero, Luciano, Economic development and wage inequality, PLOS One, vol. 12, 9/2017.

47. Škalamera-Alilović, Dunja, Rubinić, Ivan, The Tax System as a Generator of Economic Inequality in Croatia, in: Book of Proceedings: $16^{\text {th }}$ International Scientific Conference on Economic and Social Development, Varaždin, Development and Entrepreneurship Agency, 2016., pp. 459-477.

48. Stiglitz, Joseph Eugene, The Price of Inequality, New York, W. W. Norton \& Company, 2013.

49. Theil, Henri, Statistical Decomposition Analysis: With Applications in the Social and Administrative Sciences, Amsterdam, North-Holland, 1972.

50. UTIP, Inequality Project Data-Set, Austin, University of Texas, 2018.

51. van der Weide, Roy, Milanović, Branko, Inequality Is Bad for the Growth of the Poor, Policy Research Working Paper, No. 6963, World Bank, 2014.

52. Von Fintel, Dieter, Earnings bracket obstacles in household surveys - How sharp are the tools in the shed?, Stellenbosch Economic Working Paper, 08/2006.

53. Watkins, Don, Brook, Yaron, Equal is Unfair, New York, St. Martin's Press, 2016.

54. World Bank, Croatia: Economic Vulnerability and Welfare Study, Washington (Report No. 2079-HR), 2001.

55. Yu, Derek, Some factors influencing the comparability and reliability of poverty estimates across household surveys, Stellenbosch Economic Working Paper, 03/2013.

56. ZDOO [Statutory Insurance Contributions Act], Official Gazette, No.147/2002.

57. ZMP [Minimum Wage Act], Official Gazette, No.39/2013. 


\title{
Ivan Rubinić*
}

Sažetak

\section{NEJEDNAKOST PLAĆA I PROPADANJE STANDARDA RADNIKA U HRVATSKOJ}

\begin{abstract}
Ova studija potvrđuje hipotezu da hrvatski zaposlenici prolaze kroz kontinuiranu degradaciju radnih standarda uz simultanu divergenciju distribucije njihovih plaća. Korištenjem Theilovog indeksa i funkcionalne distribucije dohotka, istraživanje ukazuje na pet međusobno povezanih i štetnih tendencija. Empirijska analiza upućuje na pogoršanje standarda radne snage vidljivo kroz kontinuirani pad udjela dohotka rada u nacionalnom dohotku koji se odvija usporedno s rastom produktivnosti. Neto nejednakost u plaćama radikalno je povećana i stabilizirana na višoj razini. Pri čemu je periodično, nominalno, poboljšanje bilo većinski rezultat otpuštanja pojedinaca iz donjeg repa raspodjele plaća. Posljedično, smanjivanje disperzija plaća povećalo je ukupnu ekonomsku nejednakost. Bruto nejednakost plaća ukazuje na rastući trend, snažno i pozitivno povezan s kretanjem pripadnika s najvišim primanjima, koji doživljavaju trobrojčani porast svojih članova u analiziranom razdoblju. Rastuća nejednakost plaća između županija ukazuje na snažnu sklonost prema prekomjernoj centralizaciji zabilježenu u činjenici da je glavni grad ekskluzivna i privilegirana županija koja dosljedno izvještava iznadprosječne razine plaća. Naposljetku, nejednakost u plaćama između sektora pokazala je opći pad. Međutim, ovaj izolirani slučaj, uzimajući u obzir da je raspon između sektora s najnižim i najvišim plaćama približno dvostruko veći od komparativnog raspona između županija, i dalje ostaje dominantan katalizator nejednakosti. U skladu sa navedenim, neupitno je da trenutno stanje stvari narušava dobrobit hrvatskog radnika. Takav zaključak pred kreatore nacionalnih politika postavlja izazov suprotstavljanja s istaknutim negativnim tendencijama u cilju prevencije trenutnog egzodusa kvalificiranih radnika i uspostavljanja dugoročne makroekonomske stabilnosti.
\end{abstract}

Ključne riječi: ekonomska nejednakost; nejednakost plaća; Theil's T statistic.

Zusammenfassung

\section{LOHNGEFÄLLE UND VERSCHLECHTERUNG DES ARBEITSSTANDARDS IN KROATIEN}

Dieser Beitrag erbringt den Nachweis, dass kroatische Arbeiter ständige

* Ivan Rubinić, mag. oec., Sveučilište u Rijeci, Pravni fakultet, irubinic1@pravri.hr. 
VerschlechterungdesArbeitsstandardsunderhöhteUngleichverteilungihrerEinkommen erleben. Die Forschung entdeckte fünf sich wechselseitig stützende Tendenzen, welche mithilfe des Theil-Indexes und der funktionalen Einkommensverteilung untersucht wurden. Die empirische Analyse zeigt, dass die Verschlechterung des Arbeitsstandards in der ständigen Abnahme des Anteils des Arbeitseinkommens, welche parallel zur Produktivitätswachstum geschieht, sichtbar ist. Die Ungleichheit der Nettoeinkommen zeigt eine radikale Zunahme und Stabilisierung auf einem hohen Niveau, wo die nominale Einkommenssteigerung als Ergebnis der Entlassungen, welche in erster Linie den unteren Rand der Einkommensverteilung beeinflussen, verursacht wurde. Infolgedessen trug die geringe Ungleichverteilung der Einkommen zum Zuwachs an allgemeiner ökonomischer Ungleichheit bei. Die Ungleichheit des Bruttoeinkommens nimmt auch zu, was mit dem Zuwachs an Spitzenverdiener wegen des dreistelligen Anstiegs in diesem Bereich zu tun hat. Der Zuwachs an Ungleichheit zwischen Gespanschaften in diesem Zeitraum weist auf übermäßige Zentralisierung hin, was in der Tatsache, dass die Hauptstadt die einzige Gespanschaft mit ständigen Meldungen zum überdurchschnittlichen Einkommen darstellt, sichtbar ist. Andererseits nimmt das Einkommensgefälle zwischen Sektoren ab. Dieser isolierte Fall ist aber die Hauptursache der Ungleichheit, denn die Spannweite zwischen dem Sektor mit niedrigsten und dem Sektor mit höchsten Einkommen ist zwei Mal größer als die vergleichende Spannweite zwischen Gespanschaften. Diese Ergebnisse sind für das Wohl des kroatischen Arbeiters schädlich. Ebenfalls stellen sie eine Herausforderung für nationale Politiker dar, die nachteilige Tendenzen entgegnen müssen, um den Exodus von qualifizierten Arbeitern vorzubeugen und die langfristige makroökonomische Stabilität zu schaffen.

Schlüsselwörter: Ungleichheit; Einkommensgefälle; Theil's T statistic.

Riassunto

\section{DISEGUAGLIANZA DEI SALARI E CALO DELLO STANDARD DEI LAVORATORI IN CROAZIA}

La presente ricerca conferma l'ipotesi che i lavoratori croati attraversino una fase di continuo calo dello standard unitamente alla divergenza della distribuzione dei loro salari. Applicando l'indice Theil e la distribuzione funzionale dei redditi, l'indagine dimostra l'esistenza di cinque tendenze tra loro collegate e dannose. L'analisi empirica indica un peggioramento dello standard della forza lavoro che si individua nel progressivo calo dei redditi da lavoro sul piano nazionale in correlazione alla crescita della produttività. La divergenza nei salari al netto è in aumento e si è stabilizzata al livello più alto. Di qui il miglioramento periodico, nominale, è rappresentato perlopiù dal risultato del licenziamento di singoli dalla coda della distribuzione dei salari. Conseguentemente, la diminuzione della dispersione dei salari ha accresciuto 
la disparità economica. La diseguaglianza dei salari lordi evidenzia una crescente tendenza fortemente connessa con la circolazione dei soggetti con i redditi più elevati, i quali registrano una crescita esponenziale del loro numero nel periodo analizzato. La crescente disparità di salari tra le contee evidenzia una forte tendenza ad un'eccessiva centralizzazione, che si individua nel fatto che la capitale è la contea privilegiata ed esclusiva, che registra continuamente livelli reddituali al di sopra della media. Alla fine, la disparità dei salari tra i diversi settori ha evidenziato un calo generale. Tuttavia, tale caso isolato, considerando che il divario tra i settori a salari bassi e quelli a salari alti è più del doppio rispetto a quello tra contee, permane il dominio del catalizzatore della disparità. Alla luce di tutto ciò, è fuor di dubbio che l'attuale stato delle cose compromette il benessere dei lavoratori croati. Tale conclusione pone dinnanzi ai fautori delle politiche nazionali la sfida volta a fronteggiare tali tendenze negative al fine di ovviare all'attuale esodo di lavoratori qualificati, tendendo al raggiungimento di una duratura stabilità macroeconomica.

Parole chiave: disparità economica; diseguaglianza dei salari; Theil's $T$ statistic. 